\title{
Analysis of Changes in Shopping Habits and Causes of Food Waste Among Consumers Before and During the COVID-19 Pandemic in Poland
}

\author{
* $\quad$ Faculty of Human Nutrition, Warsaw University of Life Sciences; \\ ** Chair of Gastronomic Technology and Food Hygiene, Institute of Human Nutrition Sciences, Warsaw \\ University of Life Sciences \\ e-mail: s197097@sggw.edu.pl
}

\section{Keywords:}

food waste, consumers, survey, shopping behaviour, COVID-19 pandemic, Poland

\begin{abstract}
Food waste is a worldwide phenomenon that needs to be reduced. The causes of this problem vary widely. The study used the Computer-Assisted Web Interview method. There were 500 respondents from all over the country and among them $60 \%$ women and $40 \%$ men. The sample selection was purposeful. Before the pandemic began, the highest percentage of consumers shopped two to three times a week. As of March 2020, the frequency of this activity has decreased for every fourth respondent. Also during this period, an increase in the frequency of shopping alone was observed, as well as an increase in the number of people who outsource their shopping list to others. Nowadays, the vast majority of respondents usually create a shopping list before doing it and follow it. Before the pandemic, this was the case for only $46 \%$ of respondents, while during the pandemic it was the case for $81 \%$. Exceeding the expiration date was the most common reason for throwing products in the trash before as well as during the pandemic. Over-shopping as a cause of food waste increased almost fourfold during the pandemic. A positive aspect is noticeable for the 'I don't throw food away' response. The percentage of respondents increased from $16 \%$ to $21 \%$. During both survey periods, respondents most often indicated that they throw away fruits, vegetables, bread, and dairy products. During the COVID-19 pandemic, consumers' shopping behaviour changed. They attended grocery stores far less frequently, mostly on their own, and purchased larger quantities of products. Nonetheless, consumers planned their purchases and checked expiration dates before putting food in their shopping carts. Households were thus forced to respond quickly, adjusting their shopping behaviour. These behaviours have implications for the subsequent activities of retail merchants.
\end{abstract}

c) IOŚ-PIB

\section{INTRODUCTION}

Food waste is one of the most serious problems in the world today. The Food and Agriculture Organization of the United Nations reports that every year 1.3 billion tons of food that is still fit for consumption is wasted in the world. It constitutes one-third of the food production on our globe [FAO 2021]. This has financial implications in developing countries. Losses are estimated at $\$ 680$ billion in industrialised countries and $\$ 310$ billion in developing countries and industrialised developing countries. Food waste also contributes to water losses ( $250 \mathrm{~km}^{3} /$ year) and a decline in agricultural area of up to 28\% [FAO 2013]. According to the European Parliament [2017], the highest levels of food waste were recorded in the Netherlands (541 kg / per capita / year), Belgium (345 kg / per capita / year) and Cyprus (327 kg / per capita/ year). The lowest level was recorded in Malta and Romania (76 kg / per capita/ year) and Slovenia (72 kg / per capita/ year). The average recorded in Poland is $247 \mathrm{~kg}$ / per capita / year, which places this country in 5th place. According to the research teams of IOŚ-PIB and SGGW within the PROM project, almost 5 million tons of food is wasted in Poland [ $Ł a b a$ et al. 2020]. A division was also made into links which, to a greater or lesser extent, contribute to wasting food. These include: transport, catering, trade, agricultural production, processing and households. The PROM project is a pioneering initiative in Poland, and thanks to its activities, food waste can be counteracted. Its aim is to work out a plan for counteracting food loss and waste [PROM 2020]. The latter are the cause of the greatest losses, because as much as $60 \%$ of thrown away food comes from this link. According to the FUSIONS project, approximately 100 million tons of food waste 
is generated annually in the European Union [FUSIONS 2016]. The most commonly cited reasons for food waste in households include exceeding the best-before date and excessive shopping [Bilska et al. 2015]. Bilska et al. [2020a] showed that consumers mainly cited food spoilage as the most common reason for throwing away food. It was immediately followed by overlooking the expiration date, preparing too much food, and shopping too much. Przezbórska-Skobiej and Wiza [2021] indicated that the phenomenon of food waste affects younger people (students) as well as older people (university teachers); however, it is the younger generation that is more likely to throw away food and less likely to use leftovers and stocks. Consumers have negative attitudes towards food waste [Aschemann-Witzel 2018].However, shoppers are looking for food products with the best quality attributes [do Carmo Stangherlin et al. 2019]. Nováková et al. [2021] studying the scale of food waste in the Czech Republic showed that one- and two-person households waste (per capita) the most. This is conditioned by interchangeable demographic, socioeconomic, cultural, psychological or behavioural factors. What is noticeable here is the tendency that the higher the number of household members, the lower the amount of food waste per capita. By analysing the research, it is easy to say that the most frequently thrown out equivalents are: bread, fruit and vegetables, cold cuts and dairy products [Fanelli and Di Florio 2016; Shanes et al. 2018; Szabó-Bódi et al. 2018; Bilska et al. 2020a]. The COVID-19 pandemic spread around the world [WHO 2021], resulting in, among others, many problems in health and economics [McKeen and Stuckler 2020]. Perhaps the COVID-19 pandemic had an immediate and long-term impact on consumer behaviour [Roe et al. 2020]. Since the beginning of the COVID-19 pandemic, there have been various studies that have shown positive effects on lifestyle changes, diet, and food waste in consumers [Di Renzo et al. 2020; Bánhidi and Lacza 2020]. There have also been studies that have indicated negative lifestyle behaviours [Jia et al. 2020; Đogaš et al. 2020]. Consumer food shopping behaviour has also changed. The International Food Information Council published data showing that respondents reported an increase in the amount of food they purchased [IFIC, 2020]. This increase was in pantry items, frozen foods, and packaged foods. However, a decrease in fresh produce was observed. The accumulation of food items with impending expiration dates can increase the amount of waste generated. Consumers have begun to panic shop, accumulating stocks in both rational and irrational ways [Wang and Hao 2020]. Hao et al. [2020] indicated that online shopping satisfies consumers' needs in providing fresh food and reduces the stress and panic of stockpiling. Anxiety about one's health also caused an increased influence to shop online instead of traditional shopping [Eger et al. 2021]. Many people who stocked households with food panicked and decided to stockpile more than usual due to family health, safety, reduced anxiety, and fear of the consequences of infection [Asmundson and Taylor 2020; Kalinowski 2020]. The accumulation of food items with close to their expiration date can increase the amount of waste generated [WasteAdvantage, 2020]. 93\% of consumers reported that the shutdown caused by the COVID-19 pandemic resulted in changes in food waste [Jribi et al. 2020]. Burlea-Schiopoiu et al. [2021] documented that the impact of the COVID-19 pandemic was significant in reducing consumer food throwing behaviour. New variants of coronavirus are emerging [Płytycz 2021], which may have further implications for the entire food chain [Szczepaniak et al. 2020] and further financial stress on businesses in the agri-food system [Boughton et al. 2021]. The purpose of this study was to assess changes in consumer shopping habits and causes of food waste before and during the COVID-19 pandemic, and to learn about the most frequently discarded food items by consumers during both periods.

\section{MATERIAL AND METHODS}

The study in the form of an electronic survey (using the Computer-Assisted Web Interview method) was conducted in March and April 2021. It involved 500 respondents from all over Poland. The sample selection was purposive and consisted of subjective sampling by the researchers. The dominant group of respondents were people aged 18-26 years. (Table 1). This was due to the fact that the survey was distributed via the Internet, and this tool is used mainly by the younger part of society. The second largest group was made up of people aged 27-35. Respondents aged 46-50 were the least numerous. The largest percentage of respondents were from cities with population over 500,000, followed by rural areas. The smallest number of respondents came from cities with a population between 100,000 and 199,000 . Less than every third consumer lived in a twoperson household. Higher education and good financial situation were indicated by $55.4 \%$ of the respondents. Those who were working full-time also participated in the survey (38.4\%), while one in four were studying or studying. The survey included questions to find out the size and frequency of food shopping before and during the COVID-19 pandemic. It also asked about the frequency of selected food shopping activities, the reasons why food was thrown away in both periods (before and during the pandemic) and the frequency of throwing away selected food items. It was also assessed whether consumers accurately select indicate products bearing the statement 'should be consumed before'. Statistical analysis was also conducted. Through Pearson's correlation, the coexistence between the frequency and volume of purchases and the wastage of individual products and services was measured before and during the pandemic COVID-19. Range or standard deviation, median and kurtosis for instrument clock frequency were calculated. Both analyses were for two periods: before and during the pandemic.

\section{RESULTS AND DISCUSSION}

When asked about the frequency of their grocery shopping before the pandemic, over $50 \%$ of consumers responded 
Table 1. Characteristics of the respondents

\begin{tabular}{|c|c|}
\hline Respondents' characteristics & Share [\%] \\
\hline \multicolumn{2}{|l|}{ Gender } \\
\hline Female & 60 \\
\hline Male & 40 \\
\hline \multicolumn{2}{|l|}{ Age } \\
\hline $18-26$ & 43,8 \\
\hline $27-35$ & 11,2 \\
\hline $36-40$ & 9 \\
\hline $41-45$ & 7,8 \\
\hline $46-50$ & 6,6 \\
\hline $51-55$ & 7,6 \\
\hline $56-60$ & 7 \\
\hline$>60$ & 7 \\
\hline \multicolumn{2}{|l|}{ Place of residence } \\
\hline Village & 18,6 \\
\hline City up to 19,000 inhabitants & 9,2 \\
\hline City between 20,000 and 49,000 inhabitants & 10 \\
\hline City with 50,000 to 99,000 inhabitants & 9,8 \\
\hline City with 100,000 to 199,000 inhabitants & 8,2 \\
\hline $\begin{array}{l}\text { City between } 200,000 \text { and } 499,000 \\
\text { inhabitants }\end{array}$ & 11,8 \\
\hline City $>500,000$ inhabitants & 32,4 \\
\hline \multicolumn{2}{|l|}{ Household size } \\
\hline One-person & 11,8 \\
\hline Two-person & 31,4 \\
\hline Three-person & 23,8 \\
\hline Four-person & 18,2 \\
\hline Five-person & 8,2 \\
\hline Six-person & 3,4 \\
\hline$>$ Six-person & 3,2 \\
\hline
\end{tabular}

Source: own survey

that they did this activity two to three times per week. More than $26 \%$ said they attended such shopping four to five times a week. Other responses were once a week or less often and daily. In the pandemic era, nearly $40 \%$ of shoppers responded that they shop as often as they did before March 2020, and one in three respondents shopped less often. Over $27 \%$ of respondents also indicated that they shop for food much less frequently compared to prepandemic times. When asked about the size of their food shopping before the pandemic, consumers responded very differently. However, the predominant response was 6 to 10 food items (31.2\%), followed by 11 to 15 items (24.6\%), 16 to $20(16.8 \%), 1$ to $5(14 \%)$, and more than
20 food items (13.4\%). During a pandemic, one in three respondents said the size of their food purchases tended to be larger, while nearly one in four said larger. More than one-third of respondents answered that the volume of purchases was the same as before the pandemic, with the remainder indicating answers of rather less and less. By comparison, in Italy, one in three respondents attended grocery shopping two to three times a week [Amicarelli et al. 2021]. Before the COVID-19 pandemic, nearly $51 \%$ of Poles shopped with another person in the household, while $45 \%$ shopped alone. There were also consumers who had another person do their grocery shopping (3.8\%). During the pandemic, an increase in the frequency of shopping alone was observed among respondents $(60.8 \%)$, while a decrease was observed in the case of responses with another person from the household (27.2\%). There was also an increase in the percentage of respondents who outsource their shopping list to others (12\%). Rodgers et al. [2021] showed that there was greater supermarket avoidance among consumers during the COVID-19 pandemic. Also, the number of family members attending shopping together decreased.

Before the pandemic, shopping list preparation among respondents varied widely (Fig. 1). Three out of four respondents usually, sometimes or rarely did so. Nearly $40 \%$ of respondents usually bought products according to their prepared shopping list, and only a small percentage always did so. The most frequent answers as to whether it happened to choose food products outside the shopping list were usually or sometimes. We can see the same thing with the selection of foods that shoppers were craving for. Also, a high percentage of respondents reached for products offered as 'novelty' in order to try them. Almost $90 \%$ of them answered that they did it usually, sometimes or rarely. Nowadays, more than half of the respondents always make a shopping list, while one in four usually does so (Fig. 2). Consumers also declared that they now buy products according to their prepared shopping list. Their most frequent answers (always and usually) are almost equally distributed. In the pandemic, the percentage of people usually choosing a product off the shopping list and products they felt like buying declined in favour of responses rarely, but there is still a percentage of Poles buying products off the list or products they feel like buying. Now the largest percentage of people answered that they rarely reach for products offered as novelty in order to try them. Due to avoiding clusters of people at big-box stores, many consumers chose to shop for groceries at smaller stores. This limited choice, required planning, and reduced the desire to buy something new [Rodgers et al. 2021]. Amicarelli et al. [2021] indicates that nearly one-third of respondents indicate good habits that involve planning shopping and meal preparation.

Before the COVID-19 pandemic, nearly $70 \%$ of consumers always and usually checked the best-before date before putting a food item in their shopping cart (Fig. 3). The vast majority usually, often or sometimes bought products with a short 'use by' date if they were offered at a lower 


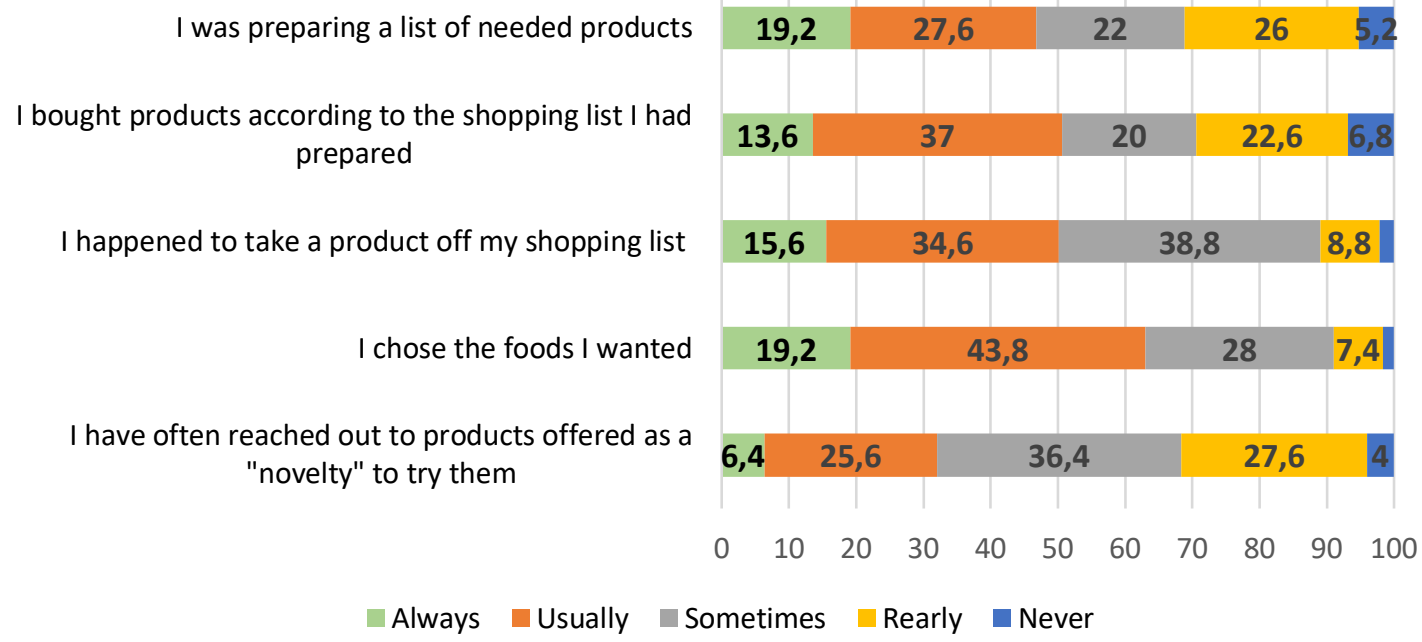

Figure 1. Frequency of listed activities when purchasing food products before the pandemic COVID-19 [\%] Source: own survey

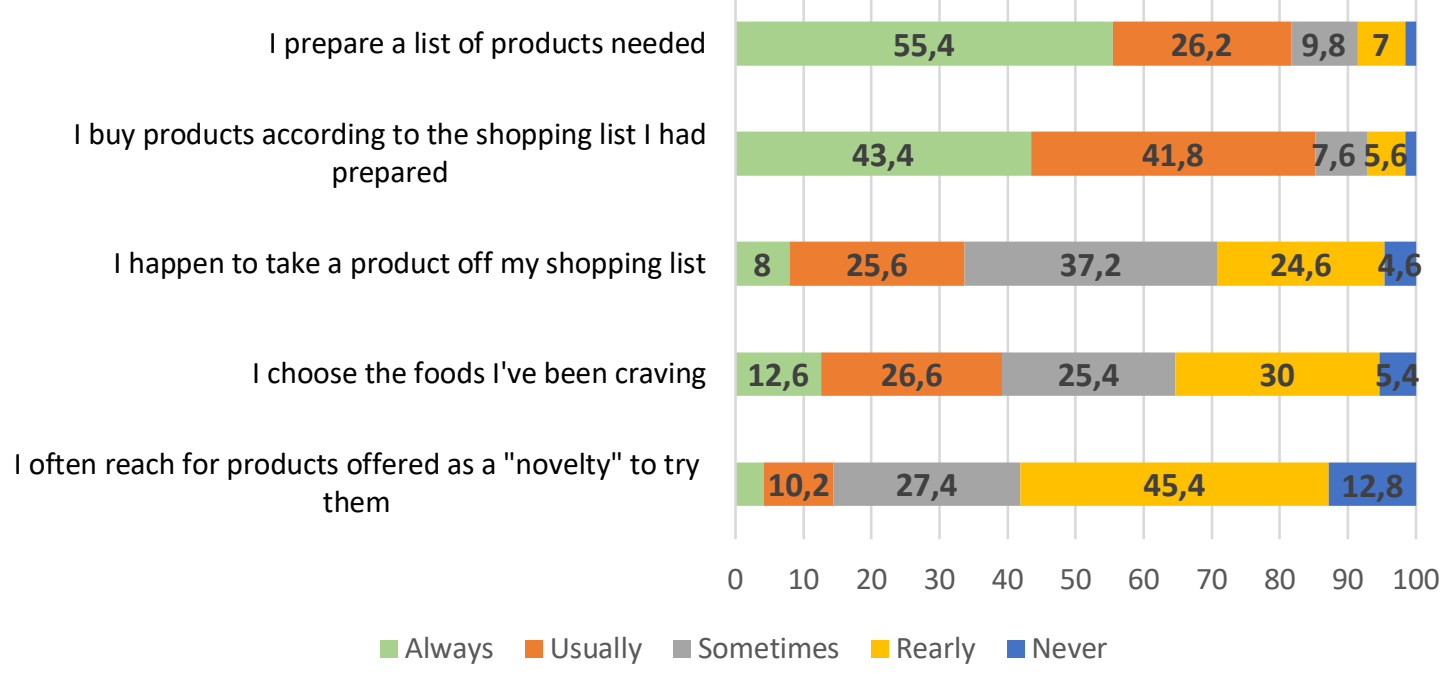

Figure 2. Frequency of listed activities when purchasing food products during the pandemic COVID-19 [\%] Source: own survey

price. More than $40 \%$ of shoppers said they never bought products whose packaging was deformed. Before the pandemic, nearly one in three respondents said they never shopped for stock, slightly less said they sometimes did, while less than one in four respondents said they often did. People in Denmark are more likely to choose products food products whose packaging is smaller in volume [Halloran et al. 2014]. After March 2020, when the pandemic occurred, more than half of those surveyed began checking the expiration date at the store, and more than a quarter did so usually (Fig. 4). In the case of buying products with shorter expiration dates, the percentage of responses usually and often decreased by a few percentage points, while the percentage of responses 'sometimes' increased slightly. There was also an increase in the percentage of never responses for consumers buying products whose packaging was deforming. In times of pandemic, respondents are more likely to shop 'in stock'. Nearly half do so usually, while nearly one in five respondents always does. During the COVID-19 pandemic, 73\% of US respondents stockpiled perishable food. More than half bought moderately more food when comparing the time before the pandemic, and nearly $26 \%$ bought slightly more food than usual [Cosgrove et al. 2021]. Nicewicz and Bilska [2021] indicated that consumers tend to shop in stock, provided the product has a longer expiry date. Also, Bilska et al. [2020b] was observed that households that waste food are more likely to purchase food products with 


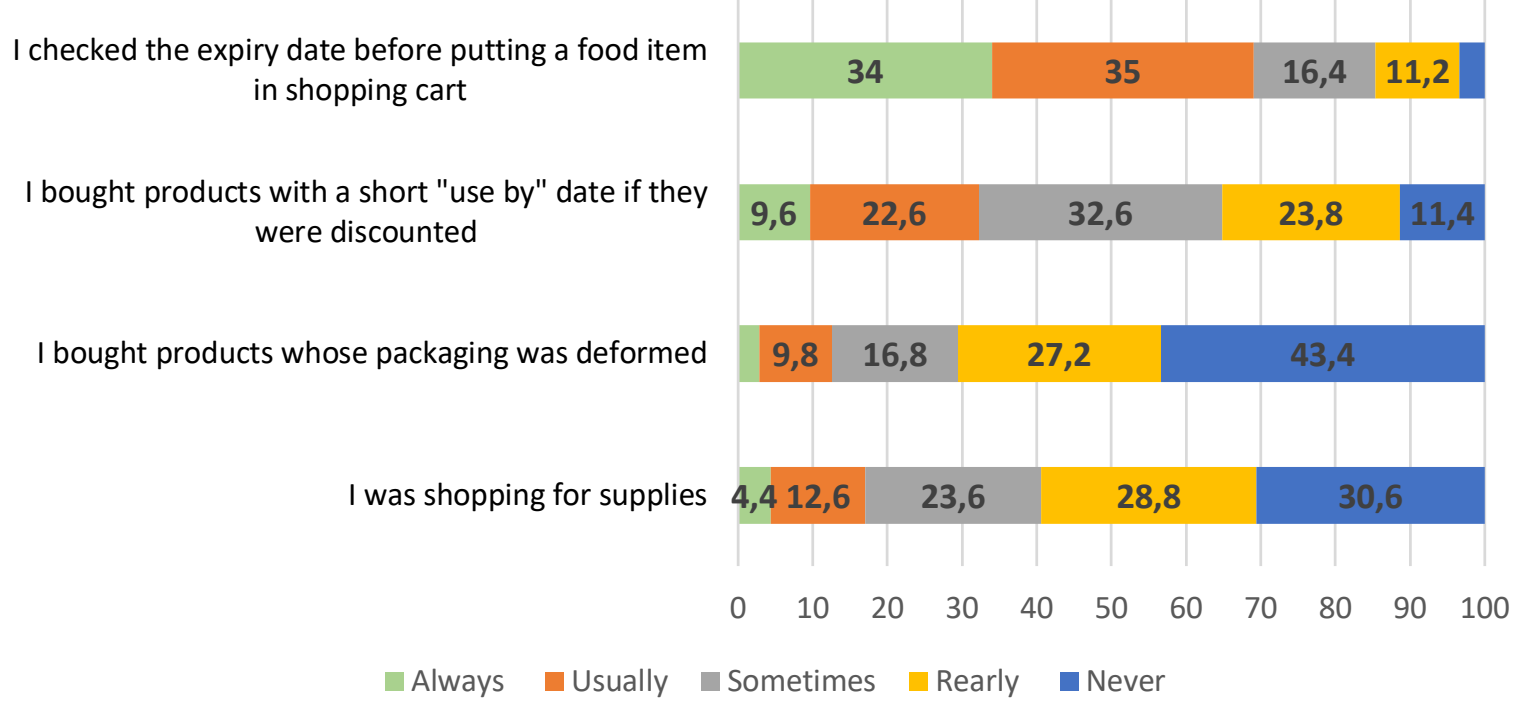

Figure 3. Frequency of listed activities when purchasing food products before the pandemic COVID-19 [\%] Source: own survey

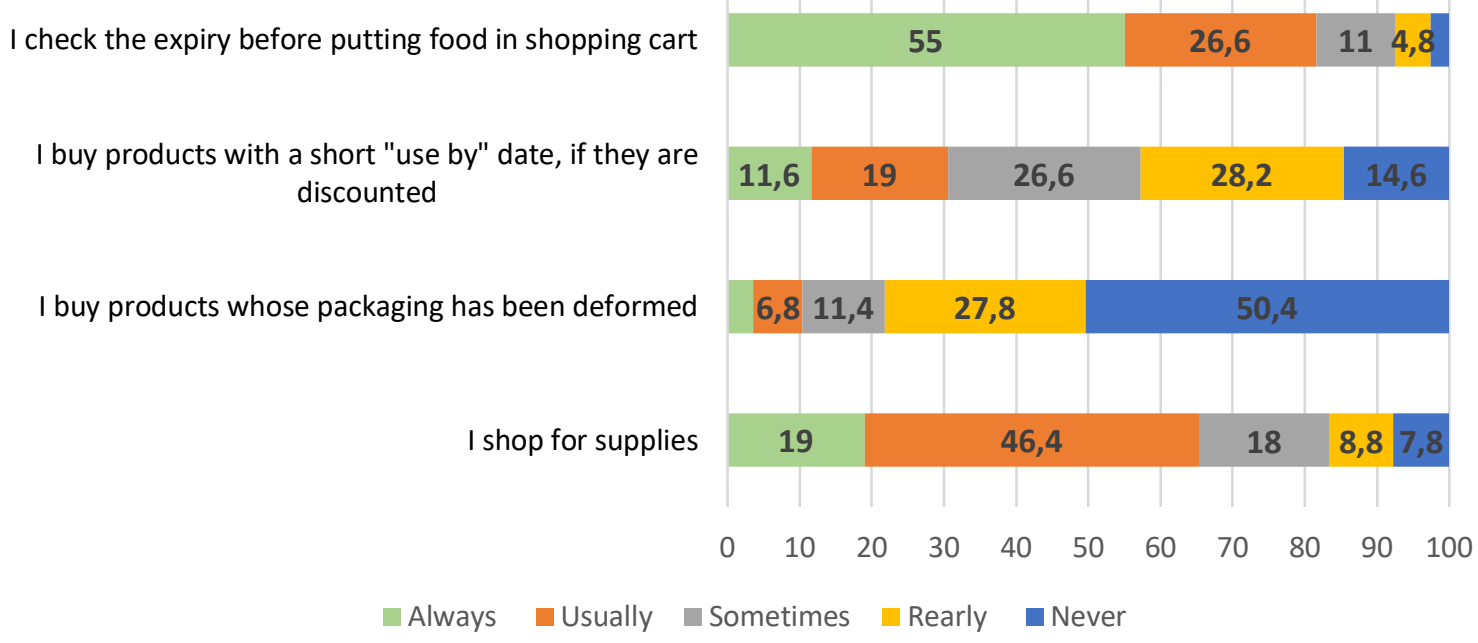

Figure 4. Frequency of listed activities when purchasing food products during the pandemic COVID-19 [\%] Source: own survey

a very short 'use by' date that are offered at a reduced price. Households classified in the 'food waste' cluster are more likely to purchase food products with a very short shelf life or a short use-by date that are offered at a discounted price. The mean of the responses on a 5-point scale where 1 is 'always' and 5 is 'never' indicated that 'usually' and 'sometimes' were the majority responses among the respondents. The largest difference in responses was seen in the mean for responses regarding shopping for supplies. Some difference is also noticeable when checking the expiration date placed on products before the product goes into the shopping cart (Table 2). Similar relationships can be observed for the median. The exception is buying products whose packaging has been deformed. Here the highest number of 'never' and 'rarely' answers appeared. Negative kurtosis is noticeable in most of the responses, meaning that there is an absence of outliers, and there appears to be a greater clustering of results around the mean. Positive kurtosis is seen for the period during the COVID-19 pandemic, with responses related to preparing a shopping list and buying products according to the shopping list (kurtosis between 1 and 2) and buying products whose packaging has become misshapen, and buying to stock up (kurtosis $<1$ ).

The main reason why food products were thrown away in households was that they had exceeded their expiration 
Table 2. The results of the mean, kurtosis, median, and standard deviation for responses regarding shopping behaviour

\begin{tabular}{|c|c|c|c|c|c|c|c|c|c|}
\hline \multicolumn{10}{|c|}{ Before the pandemic COVID-19 } \\
\hline $\mathbf{N}=\mathbf{5 0 0}$ & $\begin{array}{c}\text { I was } \\
\text { preparing } \\
\text { a list of } \\
\text { needed } \\
\text { products }\end{array}$ & $\begin{array}{l}\text { I bought } \\
\text { products } \\
\text { according } \\
\text { to the } \\
\text { shopping } \\
\text { list I had } \\
\text { prepared }\end{array}$ & $\begin{array}{c}\text { I } \\
\text { happened } \\
\text { to take a } \\
\text { product } \\
\text { off my } \\
\text { shopping } \\
\text { list }\end{array}$ & $\begin{array}{l}\text { I chose } \\
\text { the } \\
\text { foods I } \\
\text { wanted }\end{array}$ & $\begin{array}{c}\text { I have } \\
\text { often } \\
\text { reached } \\
\text { out to } \\
\text { products } \\
\text { offered as } \\
\text { a 'novelty' } \\
\text { to try them }\end{array}$ & $\begin{array}{l}\text { I checked } \\
\text { the expiry } \\
\text { date } \\
\text { before } \\
\text { putting } \\
\text { a food } \\
\text { item in } \\
\text { shopping } \\
\text { cart }\end{array}$ & $\begin{array}{l}\text { I bought } \\
\text { products } \\
\text { with a } \\
\text { short 'use } \\
\text { by' date if } \\
\text { they were } \\
\text { discounted }\end{array}$ & $\begin{array}{l}\text { I bought } \\
\text { products } \\
\text { whose } \\
\text { packaging } \\
\text { was } \\
\text { deformed }\end{array}$ & $\begin{array}{c}\text { I was } \\
\text { shopping } \\
\text { for } \\
\text { supplies }\end{array}$ \\
\hline Mean ${ }^{1}$ & 2,70 & 2,72 & 2,47 & 2,28 & 2,97 & 2,15 & 3,04 & 3,98 & 3,68 \\
\hline $\begin{array}{l}\text { Standard } \\
\text { deviation }\end{array}$ & 1,19 & 1,15 & 0,93 & 0,91 & 0,97 & 1,11 & 1,14 & 1,11 & 1,16 \\
\hline Median & 3,00 & 2,00 & 2,00 & 2,00 & 3,00 & 2,00 & 3,00 & 4,00 & 4,00 \\
\hline $\begin{array}{l}\text { Grouped } \\
\text { - median }\end{array}$ & 2,68 & 2,62 & 2,46 & 2,24 & 2,99 & 1,95 & 3,05 & 4,19 & 3,80 \\
\hline Kurtosis & $-1,09$ & $-0,89$ & $-0,14$ & 0,07 & $-0,56$ & $-0,22$ & $-0,75$ & $-0,18$ & $-0,63$ \\
\hline \multicolumn{10}{|c|}{ During the pandemic COVID-19 } \\
\hline $\mathrm{N}=\mathbf{5 0 0}$ & $\begin{array}{l}\text { I prepare } \\
\text { a list of } \\
\text { products } \\
\text { needed }\end{array}$ & $\begin{array}{c}\text { I buy } \\
\text { products } \\
\text { according } \\
\text { to the } \\
\text { shopping } \\
\text { list I had } \\
\text { prepared }\end{array}$ & $\begin{array}{l}\text { I happen } \\
\text { to take a } \\
\text { product } \\
\text { off my } \\
\text { shopping } \\
\text { list }\end{array}$ & $\begin{array}{l}\text { I choose } \\
\text { the } \\
\text { foods } \\
\text { I've } \\
\text { been } \\
\text { craving }\end{array}$ & $\begin{array}{l}\text { I often } \\
\text { reach for } \\
\text { products } \\
\text { offered as } \\
\text { a 'novelty' } \\
\text { to try them }\end{array}$ & $\begin{array}{l}\text { I check } \\
\text { the expiry } \\
\text { date } \\
\text { before } \\
\text { putting } \\
\text { food in } \\
\text { shopping } \\
\text { cart }\end{array}$ & $\begin{array}{l}\text { I buy } \\
\text { products } \\
\text { with a 'use } \\
\text { by' date, } \\
\text { if they are } \\
\text { discounted }\end{array}$ & $\begin{array}{c}\text { I buy } \\
\text { products } \\
\text { whose } \\
\text { packaging } \\
\text { has been } \\
\text { deformed }\end{array}$ & $\begin{array}{l}\text { I shop for } \\
\text { supplies }\end{array}$ \\
\hline Mean' & 1,73 & 1,80 & 2,92 & 2,89 & 3,52 & 1,73 & 3,15 & 4,14 & 2,40 \\
\hline $\begin{array}{l}\text { Standard } \\
\text { deviation }\end{array}$ & 1,00 & 0,91 & 1,00 & 1,12 & 0,98 & 1,01 & 1,22 & 1,09 & 1,12 \\
\hline Median & 1,00 & 2,00 & 3,00 & 3,00 & 4,00 & 1,00 & 3,00 & 5,00 & 2,00 \\
\hline $\begin{array}{l}\text { Grouped } \\
\text { - median }\end{array}$ & 1,54 & 1,66 & 2,92 & 2,92 & 3,60 & 1,55 & 3,22 & 4,36 & 2,24 \\
\hline Kurtosis & 1,08 & 1,74 & $-0,53$ & $-0,96$ & 0,16 & 1,56 & $-0,91$ & 0,84 & 0,08 \\
\hline
\end{tabular}

${ }^{1}$ Mean on a 5-point scale, where 1 means 'always' and 5 means'never'.

Source: own survey

date. This answer was most frequently given by respondents in both periods before and during the pandemic. During the pandemic, the number of respondents who wasted food due to unpalatable product, poor quality product and as a result of improper storage compared to before the pandemic decreased. Over-shopping as a cause of food waste increased almost fourfold during the pandemic. A positive aspect is seen in the 'I do not throw away food' response, as the percentage of respondents who do not waste food products increased (Fig 5). Cosgrove et al. [2021] found that nearly $51 \%$ respondents reported a reduction in food waste, with more than a quarter reporting an increase in food waste. The remainder, meanwhile, did not throw food away during the COVID-19 pandemic. Before the COVID-19 pandemic, consumers were more likely to throw away perishables [Kasza et al. 2020]. Also before
March 2020, nearly half of Czech residents threw away food due to spoilage, and $17 \%$ prepared too much food [Novakova et al. 2021]. Many studies, several years before the pandemic, reported responses related to buying and cooking food too often [Pearson et al. 2013; Arous et al. 2017; Hebrok and Boks 2017]. Tunisian respondents also indicate that the cause of food waste during a pandemic is eating too much food, but only $10 \%$ of them throw food in the trash. The others use the food the next day for pet food or freeze it [Jirbi et al. 2020]. In Poland, almost one-third of respondents threw away food they did not consume. One-fourth of them froze it, and only $5 \%$ fed it to animals [Bilska et al. 2015]. For Italians, $44.2 \%$ said they perceived a decrease in food waste compared to before the COVID-19 pandemic. An even higher percentage of participants from the US sample was 56.5\% [Rodgers et al. 2021]. Romanian 


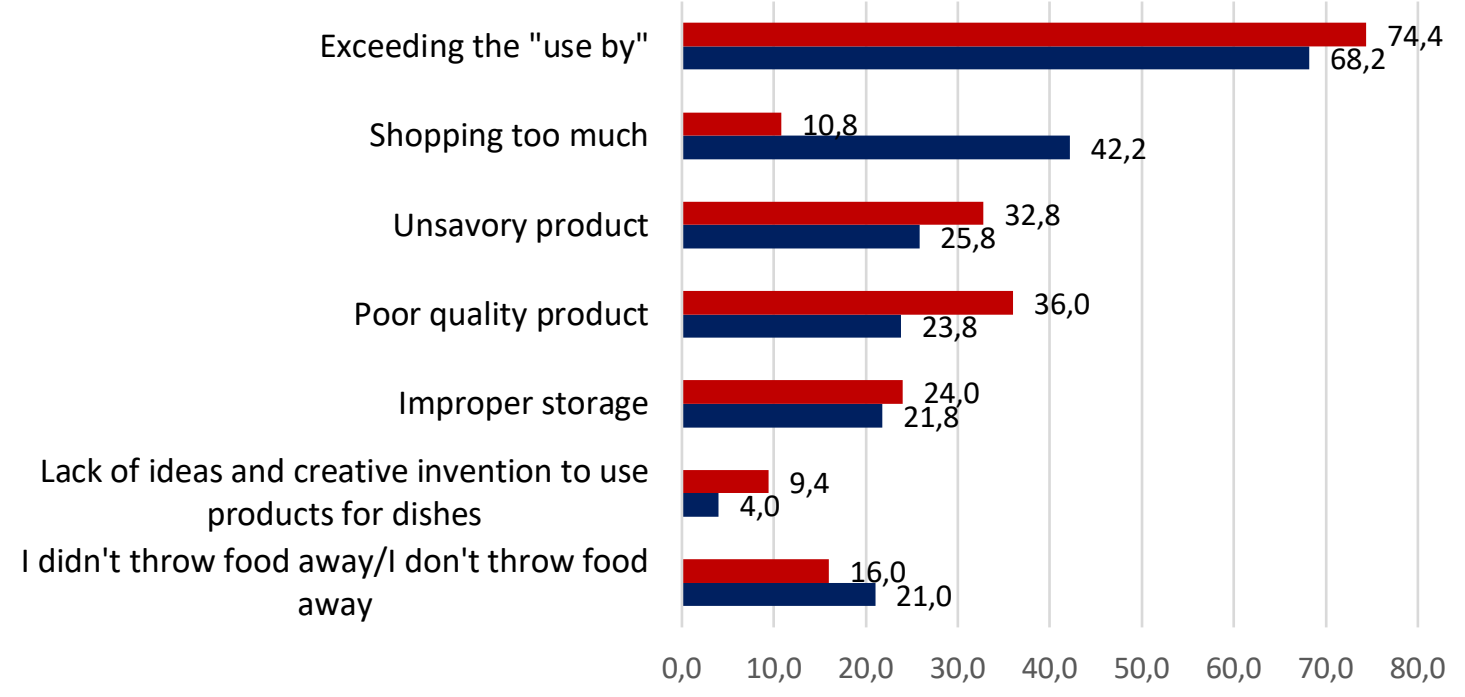

Before the pandemic During the pandemic

Figure 5. Reasons why food products were thrown away before and during the pandemic COVID-19 [\%] Source: own survey

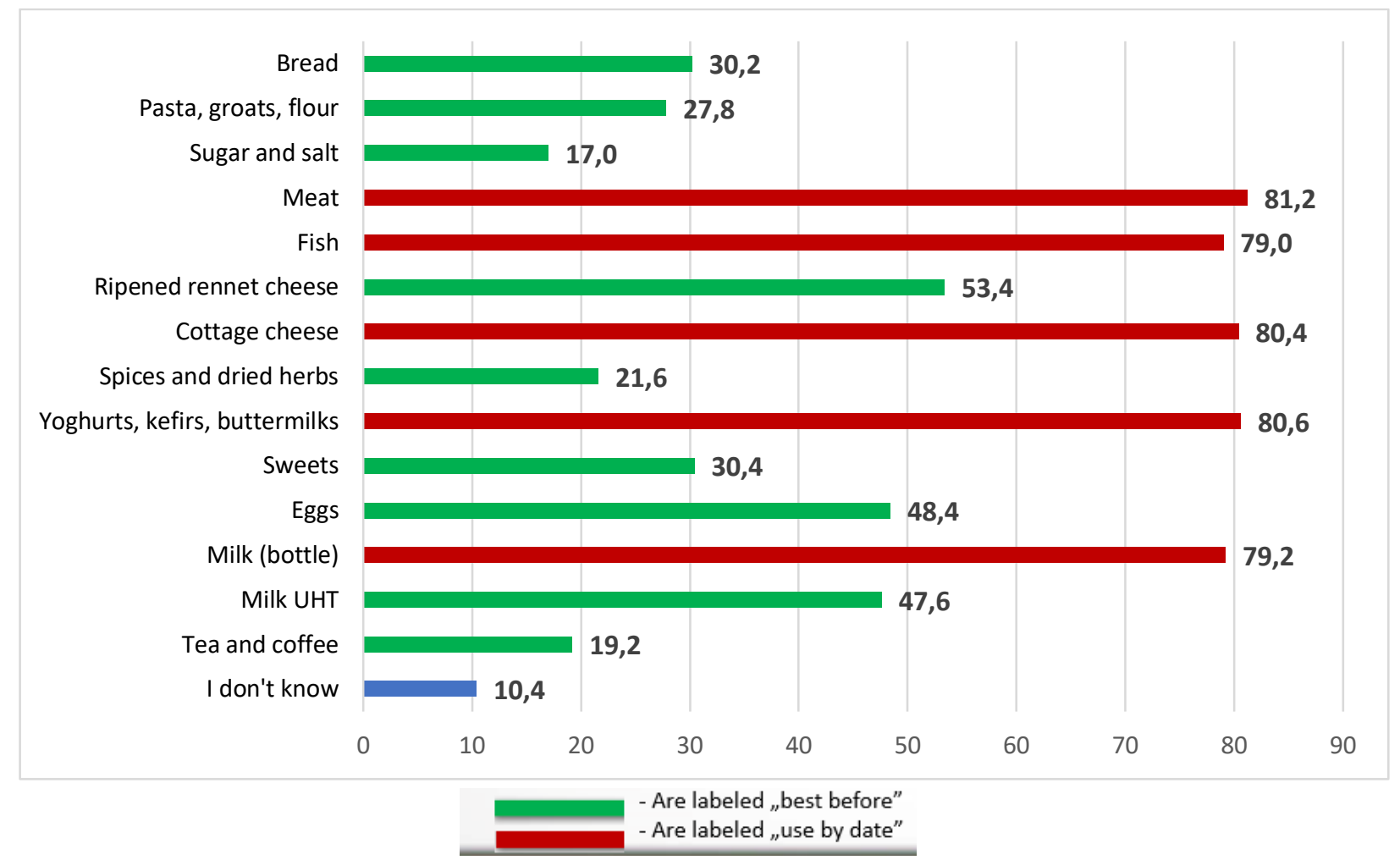

Figure 6. Consumer responses to products labelled 'use by date' during the pandemic COVID-19 Source: own survey

researchers also showed that the impact of the COVID-19 pandemic led to a decrease in food waste in this population [Burlea-Schiopoiu et al. 2021].

Respondents were asked if they knew which products were marked with a use-by date (Fig. 6). The consumers most often marked correctly: meat, yoghurts, kefirs, buttermilk, cottage cheese, bottled milk, fish. Some of the respondents also incorrectly indicated products such as: ripened rennet cheeses; eggs; UHT milk; sweets; bakery products; cereal products such as pasta, groats, and flours; spices and dried 
Table 4. Pearson's correlation results between attendance and shopping volume versus discarding selected food items before the COVID-19 pandemic

\begin{tabular}{|c|c|c|c|c|c|c|c|c|c|c|c|c|}
\hline $\begin{array}{l}\text { Specifi- } \\
\text { cation }\end{array}$ & $\begin{array}{l}\text { Frequ- } \\
\text { ency } \\
\text { of food } \\
\text { shop- } \\
\text { ping }\end{array}$ & $\begin{array}{c}\text { Volume } \\
\text { of food } \\
\text { shop- } \\
\text { ping }\end{array}$ & $\begin{array}{c}\text { Meat } \\
\text { (pork, } \\
\text { beef, } \\
\text { veal, } \\
\text { muton, } \\
\text { venison) }\end{array}$ & $\begin{array}{l}\text { Poultry } \\
\text { (whole, } \\
\text { breast, } \\
\text { tender- } \\
\text { loin, } \\
\text { thighs, } \\
\text { wings, } \\
\text { other) }\end{array}$ & $\begin{array}{c}\text { Meat } \\
\text { prepa- } \\
\text { ra-tions } \\
\text { (pates, } \\
\text { sau- } \\
\text { sages, } \\
\text { cold } \\
\text { cuts) }\end{array}$ & $\begin{array}{l}\text { Cot- } \\
\text { tage } \\
\text { che- } \\
\text { ese }\end{array}$ & $\begin{array}{c}\text { Ren- } \\
\text { neted } \\
\text { cheese }\end{array}$ & Fish & $\begin{array}{c}\text { Milk } \\
\text { (bottle) }\end{array}$ & \begin{tabular}{|c|} 
Fermen- \\
ted milk \\
drinks \\
(yoghurts, \\
kefirs, \\
butter- \\
milks)
\end{tabular} & Bread & $\begin{array}{c}\text { Fruits \& } \\
\text { vegeta- } \\
\text { bles }\end{array}$ \\
\hline $\begin{array}{c}\text { Frequency } \\
\text { of food } \\
\text { shopping }\end{array}$ & 1 &,$- \mathbf{4 5 5}$ & $-0,048$ & 0,007 & $-0,034$ & 0,063 & 0,076 & $-0,037$ & $-0,029$ & $-0,052$ & $-0,066$ &,$- 147^{* *}$ \\
\hline $\begin{array}{l}\text { Volume } \\
\text { of food } \\
\text { shopping }\end{array}$ &,$- 455^{* *}$ & 1 & 0,024 & $-0,038$ & $-0,003$ & $-0,047$ & $-0,017$ & $-0,024$ & $-0,039$ & $-0,001$ & $-0,016$ & 0,009 \\
\hline $\begin{array}{c}\text { Meat (pork, } \\
\text { beef, veal, } \\
\text { muton, } \\
\text { venison) }\end{array}$ & $-0,048$ & 0,024 & 1 & ,832 & ,708 &, $492^{* *}$ &, $427^{* *}$ &, $555^{* *}$ &, $422^{* *}$ &, $420^{* *}$ &, $419^{* *}$ &, $328^{* *}$ \\
\hline $\begin{array}{c}\text { Poultry } \\
\text { (whole, } \\
\text { breast, } \\
\text { tenderloin, } \\
\text { thighs, } \\
\text { wings, } \\
\text { other) } \\
\end{array}$ & 0,007 & $-0,038$ &, $832^{* *}$ & 1 & ,704 &, $532^{* *}$ & ,464 &, $612^{* *}$ &, $429^{* *}$ &, $411^{* *}$ &, $456^{* *}$ &, $327^{* *}$ \\
\hline $\begin{array}{c}\text { Meat } \\
\text { prepara- } \\
\text { tions } \\
\text { (pates, } \\
\text { sausages, } \\
\text { cold cuts) }\end{array}$ & $-0,034$ & $-0,003$ & ,708 & ,704 & 1 &, $624^{* *}$ &, $534^{* *}$ &, $481^{* *}$ &, $478^{* *}$ &, $482^{* *}$ &, $498^{* *}$ &, $436^{* *}$ \\
\hline $\begin{array}{l}\text { Cottage } \\
\text { cheese }\end{array}$ & 0,063 & $-0,047$ & ,492 &, $532^{* *}$ &, $624^{* *}$ & 1 & ,630 &, $391^{* *}$ &, $500^{* *}$ &, $528^{* *}$ &, $441^{* *}$ &, $406^{* *}$ \\
\hline $\begin{array}{l}\text { Renneted } \\
\text { cheese }\end{array}$ & 0,076 & $-0,017$ &, $427^{* *}$ &, $464^{* *}$ &, $534^{* *}$ &, $630^{* *}$ & 1 &, $454^{* *}$ &, $497^{* *}$ &, $525^{* *}$ &, $480^{* *}$ &, $372^{* *}$ \\
\hline Fish & $-0,037$ & $-0,024$ &, $555^{* *}$ &, $612^{* *}$ & $481^{* *}$ & ,391** &, $454^{* *}$ & 1 &, $494^{* *}$ & ,464 &, $387^{* *}$ & $269^{* *}$ \\
\hline $\begin{array}{c}\text { Milk } \\
\text { (bottle) }\end{array}$ & $-0,029$ & $-0,039$ &, $422^{* *}$ & ,429** &, $\mathbf{4 7 8}{ }^{* *}$ &, $500^{* *}$ &, $497^{* *}$ &, $494^{* *}$ & 1 &, $574^{* *}$ &, $471^{* *}$ &, $423^{* *}$ \\
\hline \begin{tabular}{|c|} 
Fermented \\
milk drinks \\
(yoghurts, \\
kefirs, \\
butter- \\
milks) \\
\end{tabular} & $-0,052$ & $-0,001$ &, $420^{* *}$ &, $\mathbf{4 1 1 ^ { * * }}$ &, $482^{* *}$ &, $528^{* *}$ &, $525^{* *}$ &, $464^{* *}$ &, $574^{* *}$ & 1 &, $634^{* *}$ &, $585^{* *}$ \\
\hline Bread & $-0,066$ & $-0,016$ &, $419^{* *}$ &, $456^{* *}$ &, $498^{* *}$ &, $441^{* *}$ &, $480^{* *}$ &, $387^{* *}$ &, $471^{* *}$ &, $634^{* *}$ & 1 &, $703^{* *}$ \\
\hline $\begin{array}{c}\text { Fruits \& } \\
\text { vegetables }\end{array}$ &,$- 147^{* *}$ & 0,009 &, $328^{* *}$ &, $327^{* *}$ &, $436^{* *}$ &, $406^{* *}$ & , 372 &, $269^{* *}$ &, $423^{* *}$ &, $585^{* *}$ &, $703^{* *}$ & 1 \\
\hline
\end{tabular}

Source: own survey 
Table 5. Pearson's correlation results between attendance and shopping volume versus discarding selected food items during the COVID-19 pandemic

\begin{tabular}{|c|c|c|c|c|c|c|c|c|c|c|c|c|}
\hline $\begin{array}{l}\text { Specifica- } \\
\text { tion }\end{array}$ & $\begin{array}{l}\text { Frequ- } \\
\text { ency } \\
\text { of food } \\
\text { shop- } \\
\text { ping }\end{array}$ & $\begin{array}{c}\text { Volume } \\
\text { of food } \\
\text { shop- } \\
\text { ping }\end{array}$ & $\begin{array}{c}\text { Meat } \\
\text { (pork, } \\
\text { beef, } \\
\text { veal, } \\
\text { muton, } \\
\text { venison) }\end{array}$ & $\begin{array}{l}\text { Poultry } \\
\text { (whole, } \\
\text { breast, } \\
\text { tenderlo- } \\
\text { in, thighs, } \\
\text { wings, } \\
\text { other) }\end{array}$ & $\begin{array}{c}\text { Meat } \\
\text { prepa- } \\
\text { rations } \\
\text { (pates, } \\
\text { sau- } \\
\text { sages, } \\
\text { cold } \\
\text { cuts) }\end{array}$ & \begin{tabular}{|} 
Cot- \\
tage \\
cheese
\end{tabular} & $\begin{array}{c}\text { Ren- } \\
\text { neted } \\
\text { cheese }\end{array}$ & Fish & $\begin{array}{c}\text { Milk } \\
\text { (bottle) }\end{array}$ & $\begin{array}{c}\text { Fermen- } \\
\text { ted milk } \\
\text { drinks } \\
\text { (yoghurts, } \\
\text { kefirs, but- } \\
\text { termilks) }\end{array}$ & Bread & $\begin{array}{l}\text { Fru- } \\
\text { its \& } \\
\text { vege- } \\
\text { tables }\end{array}$ \\
\hline $\begin{array}{c}\text { Frequency } \\
\text { of food } \\
\text { shopping }\end{array}$ & 1 &,$- 556^{* *}$ & 0,071 & 0,008 & 0,038 & 0,045 & 0,037 & 0,084 &, $152^{* *}$ &, $178^{* *}$ &, $119^{* *}$ & $145^{* *}$ \\
\hline $\begin{array}{l}\text { Volume } \\
\text { of food } \\
\text { shopping }\end{array}$ &,$- 556^{* *}$ & 1 & 0,033 & 0,060 & 0,027 & $-0,024$ & $-0,012$ & $-0,015$ & $-0,080$ &,$- 154^{* *}$ &,$- 112^{*}$ &,$- 151^{* *}$ \\
\hline $\begin{array}{c}\text { Meat } \\
\text { (pork, } \\
\text { beef, veal, } \\
\text { muton, } \\
\text { venison) }\end{array}$ & 0,071 & 0,033 & 1 &, $865^{* *}$ &, $763^{* *}$ &, $540^{* *}$ &, $516^{* *}$ &, $616^{* *}$ &, $465^{* *}$ &, $470^{* *}$ & , $471^{* *}$ & ,390** \\
\hline \begin{tabular}{|c} 
Poultry \\
(whole, \\
breast, \\
tenderloin, \\
thighs, \\
wings, \\
other)
\end{tabular} & 0,008 & 0,060 &, $865^{* *}$ & 1 & ,770** &, $551^{* *}$ &, $532^{* *}$ &, $618^{* *}$ & ,479** &, $476^{* *}$ &, $492^{* *}$ &, $386^{* *}$ \\
\hline $\begin{array}{c}\text { Meat } \\
\text { prepa- } \\
\text { rations } \\
\text { (pates, } \\
\text { sausages, } \\
\text { cold cuts) }\end{array}$ & 0,038 & 0,027 &, $763^{* *}$ & ,770** & 1 &, $670^{* *}$ &, $622^{* *}$ &, $515^{* *}$ &, $548^{* *}$ &, $555^{* *}$ &, $576^{* *}$ & ,510** \\
\hline $\begin{array}{l}\text { Cottage } \\
\text { cheese }\end{array}$ & 0,045 & $-0,024$ &, $540^{* *}$ &, $551^{* *}$ &, $670^{* *}$ & 1 & ,782 &, $472^{* *}$ & ,570** & ,619** &, $576^{* *}$ &, $547^{* *}$ \\
\hline $\begin{array}{l}\text { Renneted } \\
\text { cheese }\end{array}$ & 0,037 & $-0,012$ &, $516^{* *}$ &, $532^{* *}$ &, $622^{* *}$ &, $782^{* *}$ & 1 &, $476^{* *}$ &, $554^{* *}$ &, $545^{* *}$ & ,571** &, $497^{* *}$ \\
\hline Fish & 0,084 & $-0,015$ &, $616^{* *}$ &, $618^{* *}$ &, $515^{* *}$ &, $472^{* *}$ &, $476^{* *}$ & 1 &, $513^{* *}$ & $429^{* *}$ &, $397^{* *}$ &, $302^{* *}$ \\
\hline $\begin{array}{c}\text { Milk } \\
\text { (bottle) }\end{array}$ &, $152^{* *}$ & $-0,080$ &, $465^{* *}$ & ,479** &, $548^{* *}$ &, $570^{* *}$ &, $554^{* *}$ &, $513^{* *}$ & 1 & ,664 &, $623^{* *}$ &, $515^{* *}$ \\
\hline $\begin{array}{c}\text { Fermented } \\
\text { milk drinks } \\
\text { (yoghurts, } \\
\text { kefirs, but- } \\
\text { termilks) }\end{array}$ &, $178^{* *}$ &,$- 154^{* *}$ & ,470** &, $476^{* *}$ &, $555^{* *}$ &, $619^{* *}$ &, $545^{* *}$ &, $429^{* *}$ &, $664^{* *}$ & 1 &, $705^{* *}$ & ,716** \\
\hline Bread &, $119^{* * *}$ &,$- 112^{*}$ &, $471^{* *}$ &, $492^{* *}$ &, $576^{* *}$ &, $576^{* *}$ & ,571** &, $397^{* *}$ &, $623^{* * *}$ &, $705^{* *}$ & 1 & ,756** \\
\hline \begin{tabular}{|c|c|} 
Fruits \& \\
vegetables
\end{tabular} &, $145^{* *}$ &,$- 151^{* *}$ & ,390** &, $386^{* *}$ &, $510^{* *}$ &, $547^{* *}$ &, $497^{* *}$ &, $302^{* *}$ &, $515^{* *}$ & ,716** &, $756^{* *}$ & 1 \\
\hline
\end{tabular}

Source: own survey 
herbs; and teas and coffees, as well as sugar and salt, which are marked as 'best before' or, in the eyes of the law, do not have to be marked with the 'best before' date. More than $10 \%$ of respondents did not know which products have a 'use by' label.

The following list brings together those products that have a 'use by' label and those that are estimated to be the most frequently thrown away by consumers [Bilska et al. 2020a] (Table 3). Before as well as during the COVID-19 pandemic, the least frequently discarded food item was fish. For the 'always' response, few people threw away any of the foods listed, no difference whether it was before or during the pandemic. In both survey periods, consumers were most likely to indicate that they were throwing away fruits, vegetables, bread and dairy. During the COVID-19 pandemic, the frequency of throwing away food products decreased, but the percentage of people who responded 'I don't buy' for animal products and baked goods also increased. Despite the fact that two-thirds of consumers always look at the best-before date for cold cuts and $60 \%$ for fermented milk drinks [Nicewicz and Bilska 2021], these are still the products that the public throws away most often. It is possible that during the pandemic, consumers dropped certain foods from their diet. In Italy, the most frequently thrown away products were fruit (22\%), vegetables and legumes (19\%) and fish and fish products (14\%). This is followed by meat and meat products, milk and milk products, pasta and rice, and ready meals, which accounted for a few percent [Amicarelliand Bux 2021]. Bilska et al. [2015] indicate that the most commonly discarded products by respondents are bread, vegetables, yoghurt, fruit, milk, potatoes, meat and prepared meals. Products purchased in bulk were not often wasted by respondents [Bilska et al. 2020b]. Novakova et al. [2021] points out that it is possible to reduce rests from vegetables (26\%), bread (23\%), home-made meals (16\%) and fruit (13\%). Kasza et al. [2020] believe that almost $32 \mathrm{~kg} /$ per capita/per year of total food waste could have been avoided in Hungary. Pearson correlation results indicate statistically significant results for the relationship between frequency of grocery store attendance and amount of grocery shopping $(p<0.001)$ (Tables 4 and 5). Grocery store attendance also influenced vegetable and fruit waste (before and during the COVID-19 pandemic) and milk, fermented milk drinks, and bread (during the pandemic). Also statistically significant was the relationship between discarded food items in both study periods - before and during the COVID-19 pandemic.

\section{CONCLUSIONS}

During the COVID-19 pandemic, consumers' shopping behaviours changed. They were more likely to shop on their own or have someone else make their shopping list. They were much less likely to visit grocery stores and buy larger quantities of products. Despite planning their shopping and checking the expiry date before putting it in the basket, a significant number of respondents throw away food for various reasons, but the main determinant of this phenomenon is exceeding the expiry date. The most commonly wasted foods are fruits, vegetables, bread and dairy. Most consumers were able to correctly identify products with best-before dates, but there were also incorrect answers indicating products with 'best before' labels. There is a noticeable progress in the scope of nonwaste of food products; however, in order to improve it, it is justified to conduct educational campaigns by the state or non-governmental organizations, concerning food management and skilful use of food products. This will build consumer awareness of the importance of food stewardship in relation to saving the degrading planet and environment. This will lead to an intensification of behaviour in the area, which will help in the recovery of our environment and the planet. Our study contributes to a better understanding of how the COVID-19 pandemic affects consumer shopping behaviour and food waste in Poland. Consumers are changing their behaviours to cope with the crisis and limiting grocery store trips, which could be an important fact for the retail food industry. Perhaps this will persuade retailers to sell on online platforms, especially since it is unknown how much longer the pandemic may last and how dangerous coronavirus variants may become. Hopefully, good consumer practices will remain in the community even after the pandemic ends, and producers and traders will find ways to adapt to ever-changing consumer behaviour.

\section{REFERENCES AND LEGAL ACTS}

Amicarelli V., Bux C. 2021. Food waste in Italian households during the Covid-19 pandemic: a self-reporting approach. Food Security 13:25-37. https://doi. org/10.1007/s12571-020-01121-z

Amicarelli, V., Tricase, C., Spada, A., Bux, C. 2021. Households' Food Waste Behavior at Local Scale: A Cluster Analysis after the COVID-19 Lockdown. Sustainability, 13, 3283. https://doi.org/10.3390/su13063283
Arous S. A., Capone R., Philipp D., Haddadi Y., El Bilali H., Bottalico F., Hamidouche M. 2017. Exploring household food waste issue in Algeria. AGROFOR International Journal, 2(1), 55-67.

Aschemann-Witzel J. 2018. Consumer perception and preference for suboptimal food under the emerging practice of expiration date based pricing in supermarkets. Food Quality and Preference 63,119-128 
Asmundson G.J.G., Taylor S. 2020. Coronaphobia: Fear and the 2019-nCoV outbreak. Journal of Anxiety Disorders, 70, 102196, https://doi.org/10.1016/j. janxdis.2020.102196

Bánhidi, M., Lacza, G. 2020. Lifestyle changes during Covid-19 period in Hungary-feedback of university students. World Leis. J. 62, 325-330.

Bilska B., Grzesińska W., Tomaszewska M., Rudziński M. 2015. Marnotrawstwo żywności jako przykład nieefektywnego zarządzania w gospodarstwach domowych. Stowarzyszenie Ekonomistów Rolnictwa i Agrobiznesu. Roczniki Naukowe. Tom XVII, zeszyt 4.

Bilska B, Tomaszewska M, Kołożyn-Krajewska D. 2020a. Analysis of the behaviors of Polish consumers in relation to food waste. Sustainability. 12(1):1-16. doi:10.3390/ su12010304.

Bilska B., Tomaszewska M., Kołożyn-Krajewska D., Piecek M. 2020b. Segmentation of Polish Households Taking into Account Food Waste. Foods, 9, 379; doi:10.3390/ foods9040379

Boughton D., Goeb J., Lambrecht I., Headey D., Takeshima H., Mahrt K., Masias I., Goudet S., Ragasa C., Maredia M. K., Minten B., Diao X. 2021. Impacts of COVID-19 on agricultural production and food systems in late transformin Southeast Asia: The case of Myanmar. Agricultural Systems, volume 188, https://doi. org/10.1016/j.agsy.2020.103026

Burlea-Schipoiu A., Ogarca R. F., Barbu C. M., Craciun L., Baloi I. C., Mihai L. S. 2021. The impact of COVID-19 pandemic on food waste behaviour of young People.

Cosgrove K. Vizcaino M., Wharton C. 2021. COVID-19Related Changes in Perceived Household Food Waste in the United States: A Cross-Sectional Descriptive Study. Int. J. Environ. Res. Public Health, 18, 1104. https://doi. org/10.3390/ijerph18031104

Di Renzo L., Gualtieri P., Pivari F., Soldati L., Attinà A., Cinelli G., Leggeri C., Caparello G., Barrea L., Scerbo F., Esposito E., De Lorenzo A. 2020. Eating habits and lifestyle changes during COVID-19 lockdown: An Italian survey. J. Transl. Med.,18, 1-15.

do Carmo Stangherlin I., Duarte Ribeiro J.L., Barcellos M. 2019. "Consumer behaviour towards suboptimal food products: a strategy for food waste reduction", British Food Journal, Vol. 121 No. 10, 201

Đogaš Z., Kalcina L.L., Dodig I.P., Demirovi'c S., Madirazza K., Vali'c M., Pecoti'c R. 2020. The effect of COVID-19 lockdown on lifestyle and mood in Croatian general population: A cross-sectonal study. Croat. Med. J. 61, 309-318.

Eger L., Komárková L., Egerová D., Mičík M. 2021. The effect of COVID-19 on consumer shopping behaviour: Generational cohort perspective. Journal of Retailing and Consumer Services, 61, 102542.

European Parliament. Food Waste: The Problem in the EU in Numbers [Infographic]. 2017. http://www.europarl.europa. eu/news/en/headlines/society/20170505STO73528/foodwaste-the-problem-in-the-eu-in-numbersinfographic. Accessed on 15 June 2021.
Fanelli R. M., Di Florio A. 2016. Domestic food waste, gap in times of crisis. Italian Review of Agricultural Economics, 71(2), 111-125.

FAO. 2013. Food wastage footprint: Impact on natural resources. Summary report. Rome: FAO. (Accessed 15 June 2021).

FAO. 2021. The State of Food Security and Nutrition in the World 2021 (SOFI 2021). FAO. (Accessed 31 August 2021).

FUSIONS. 2016. Estimates of European food waste levels. https://www.eu-fusions.org/phocadownload/ Publications/Estimates $\% 20$ of\%20European $\% 20$ food\%20waste\%20levels.pdf (Accessed 31 August 2021).

Halloran A., Clement J., Kornum N., Bucatariu C., Magid J. 2014. Addressing food waste reduction In Denmark. Food Policy 49 (1) : 294-301. DOI 10.1016/j. foodpol.2014.09.005.

Hao N., Wang H. H., Zhou Q. 2020. The impact of online grocery shopping on stockpile behavior in Covid-19. China Agricultural Economic Review, 12, 459-470. 277.

Hebrok, M., Boks C. 2017. Household food waste: Drivers and potential intervention points for design: An extensive review. Journal of Cleaner Production, 151, 380-392

International Food Information Council (IFIC). 2020. COVID-19: Impact on Food Purchasing, Eating Behaviors and Perceptions of Food Safety. https://foodinsight.org/ wp-content/uploads/2020/04/COVID-19-ConsumerResearch.April2020.pdf. (Accessed 15 June 2021).

Jia P., Liu L., Xie X., Yuan C., Chen H., Guo B., Zhou J., Yang S. 2020. Impacts of COVID-19 lockdown on diet patterns among youths in China: The COVID-19 Impact on Lifestyle Change Survey (COINLICS). Appetite, 158, 105015.

Jirbi S., Ismail H. B., Doggui D., Debbabi H. 2020. COVID-19 virus outbreak lockdown: What impacts on household food wastage? Environment, Development and Sustainability https://doi.org/10.1007/s10668-02000740-y

Kalinowski, S. 2020. Od paniki do negacji: zmiana postaw wobec COVID-19, Wieś i Rolnictwo, (3) (188), s. 45-65. doi: 10.53098/wir032020/03.

Kasza G., Dorkó A., Kunszabó A., Szakos D. 2020. Quantification of Household Food Waste in Hungary: A Replication Study Using the FUSIONS Methodology. Sustainability, 12, 3069.

Łaba S., Bilska B., Tomaszewska M., Łaba R., Szczepański K., Tul-Krzyszczuk A., Kosicka-Gębska M., KołożynKrajewska D. 2020. Próba oszacowania strat i marnotrawstwa żywności w Polsce. Przemysł Spożywczy. Tom 74. DOI 10.15199/65/2020.11.2

McKeen, M. Stuckler, D. 2020. If the world fails to protect the economy, COVID-19 will damage health not just now but also in the future. Nat. Med., 26, 640-642.

Nicewicz R., Bilska B. 2021. Postrzeganie przez konsumentów produktów z końcową data ważności. Przemysł Spożywczy. Tom 75. DOI 10.15199/65.2021.6.6 
Nováková P., Hák T., Janoušková S. 2021. An Analysis of Food Waste in Czech Households-A Contribution to the International Reporting Effort. Foods, 10, 875.

Pearson D., Minehan M., Wakefield-Rann R. 2013. Food waste in Australian households: Why does it occur? Australasian-Pacific Journal of Regional Food Studies, 3, 118-132.

Płytycz B. 2021. Ewolucja koronawirusa SARS-CoV-2 a skuteczność szczepionek przeciw COVID-19 (z addendum o pochodzeniu SARS-CoV-2). Wszechświat. Pismo przyrodnicze. Polskie Towarzystwo Przyrodników im. Kopernika. Tom 122, Nr 4-6.

PROM. 2020. https://projektprom.pl/index.php/oprojekcie/cel-projektu (Accessed 31 August 2021).

Przezbórska-Skobiej L., Wiza P.L. 2021. FoodWaste in Households in Poland-Attitudes of Young and Older Consumers towards the Phenomenon of FoodWaste as Demonstrated by Students and Lecturers of PULS. Sustainability,13, 3601. https://doi.org/10.3390/ su13073601

Rodgers R.F., Lombardo C., Cerolini S., Franko D.L., Omori M., Linardon J., Guillaume S., Fischer L., Fuller-Tyszkiewicz M. 2021. "Waste not and stay at home" evidence of decreased food waste during the COVID-19 pandemic from the U.S. and Italy. Appetite 160, 105110 https:// doi.org/10.1016/j.appet.2021.105110

Roe B.E., Bender K., Qi D. 2020. The Impact of COVID-19 on Consumer Food Waste. Applied Economic Perspectives and Policy, volume 43, number 1, pp. 401-411. doi:10.1002/aepp.13079

Shanes K., Dobernig K., Gözet B. 2018. Food waste matters: A systematic review of household food waste practices and their policy implications. Journal of Cleaner Production, 182(1), 978-991.

Szabó-Bódi B., Kasza, G., Szakos D. 2018. Assessment of household food waste in Hungary. British Food Journal, 120, 625-638.

Szczepaniak I., Ambroziak Ł., Dróżdż J., Mroczek R. 2020. Przemysł spożywczy w obliczu pandemii COVID-19. Przemysł Spożywczy, Tom 74, nr 5, 2-7

Wang H. H., Hao N. 2020. Panic buying? Food hoarding during the pandemic period with city lockdown. Journal of Integrative Agriculture, 9, 2916-2925.

WasteAdvantage. 2020. The Impact of COVID-19 on the Waste and Recycling Industry. WasteAdvantage URL. https://wasteadvantagemag.com/the-impact-ofcovid-

19-on-the-waste-and-recycling-industry (Accessed 15 June 2021)

World Health Organization (WHO), 2021. COVID-19 weekly epidemiological update.

https://www.who.int/publications/m/item/weeklyepidemiological-update-on-covid-19---15-june-2021. (Accessed 15 June 2021). 